\title{
Application of nursing process in community health to patient with pressure injury
}

\author{
Naila Albertina Oliveira, $, 2,2 *$ Kamila A. Bazan, ${ }^{4}$ Anne P.G. Leite, ${ }^{5}$ Simone C. Cardoso,,${ }^{5}$ Marilene N. Silva, ${ }^{5}$ \\ Carla R. M. Miura ${ }^{2}$
}

\begin{abstract}
Introduction: Nursing is a science whose main objective is the care process. From preventive approach viewpoint as well as in health promotion, nurse's main task is to guide and execute the care practice as means to reduce the prevalence of pressure injuries (PI). Objective: To report the implementation of the nursing process in the phases of history, nursing diagnoses, planning, and educational interventions towards a patient with pressure injury bedridden and assisted by the primary health care team. Method: This is a clinical case study, using nursing process in the phases of history, nursing diagnosis, planning, intervention, and results evaluation. Patient was chosen during a home visit. Data were collected through data collection and interview phase while forms were filled up via "check list". Nursing diagnosis was later elaborated using NANDA-1 taxonomy while interventions followed NIC and NOC taxonomies in order to meet human basic needs in line with Wanda Horta. Results: After data collection, NANDA-1 diagnoses were found as follows: pressure ulcer risk, tissue integrity impaired, feeding self-care deficit, infection risk, fall risk and acute pain. Related factors analyses and defining characteristics outlined NOC objectives and interventions (NIC) for patient care and for caregivers guidance. It was observed that well-oriented caregivers can promote injury prevention actions while improving life quality of a bedridden patient with self-care limitations related to aging process. Final considerations: Application of nursing process promotes effectiveness as well as quality in care and guidance towards the patient, while nursing role should be emphasized when guiding, teaching and raising awareness among elderly patients as well as their caregivers in home care.
\end{abstract}

Keywords: Pressure injury; Nursing process; Nursing; Community health nursing; Wounds.

\section{Introduction}

Nursing is a science whose main objective is the care process. From preventive approach viewpoint as well as in health promotion, nurse's main task is to guide and execute the care practice as means to reduce the prevalence of pressure injuries (PI). Unlike other skin changes, PI's have been main sources of concerns towards primary care nurses' performance as they represent a public health problem leading to either physical problems or emotional disorders that directly affect health problems epidemiology.-2

The American National Pressure Ulcer Advisory
1. Programa de Pós-Doutorado em Enfermagem, UNIFESP. São Paulo, SP, Brazil.

2. Departamento de Enfermagem Cirúrgica, Escola de Enfermagem, UNIFESP. São Paulo, SP, Brazil.

3. Departamento de Enfermagem da Universidade Paulista. Jundiaí, SP, Brazil.

4. Faculdade de Enfermagem, Braz Cubas Educação. Mogi das Cruzes, SP, Brazil.

5. Faculdade de Enfermagem, Universidade Paulista. Limeira, SP, Brazil.

* Correspondence address:

Av.Armando Giassetti, 577

Jundiaí, SP, Brasil, CEP:04024002

E-mail: nailaa.oliveira@gmail.com

ORCID: https://orcid.org/ 0000-0001-8340-5334

BJHBS, Rio de Janeiro, 2021;20(1):84-91

DOI: $10.12957 /$ bjhbs.2021.59750

Received on 08/03/2020. Approved on 10/26/2020.

Panel (NPUAP) has changed the term "pressure ulcer" to PI, a skin damage potentially affecting underlying soft tissues, usually bony prominences, e.g. occipital, scapula, elbow, sacral region, malleolus and calcaneus. ${ }^{3}$. Occurrence of this type of injury causes various physical and psychological disorders in patients such as discomfort, pain, suffering, and emotional attachment to injury, which hinders PI healing process and increases complications risk. ${ }^{1}$

In the international scenario, death incidence related to PI varies from $4.5 \%$ to $25.2 \%$ in the United Kingdom, from $2.9 \%$ to $8.34 \%$ in Spain, about $14.8 \%$ in England and 19.1\% in USA, as described by home care teams. In Brazil, studies on PI prevalence and incidence are scarce; however, in relation to home care, there are studies showing that the risk of developing PI varies between $41.2 \%$ and $59 \%$ while prevalence varies from $8 \%$ to $23 \%$. This fact is distressing, as PI can be prevented in up to $95 \%$ of cases, as determined by the Ibero-American Society of ulcers and wounds. ${ }^{5}$

Caring for people with PI should occur in all health care levels as well as Primary Health Care, where care is mainly performed by the nursing team. In turn, the nurse is the health team member in charge of health 
promotion actions and nursing care specific protocols towards PI care. ${ }^{2,6}$

Nurse seeks to integrate health sciences knowledge by the use of conceptual and theorist models to assess basic human needs in a holistic and integral way. Among all the theoretical references, Maslow's Theory on Basic Human Needs (BHN) was used to support the elaboration of the clinical case study herein presented.

BHN theory encompasses Maslow's Human Motivation Theory (1970), whereas João Mohana's (1964) theory classifies human needs into psychobiological, psychosocial and psychospiritual. According to this theory, human needs obey a priority order and whenever a person fulfils a given need, another one takes in its place, demanding constant satisfaction of listed needs.

According to Horta, ${ }^{7}$ humans belong to a dynamic universe, where they undergo an imbalance whenever their basic needs are not met or are partially met for a long period, which can cause illness. A case study assessed patient's needs in order to enable efficient interventions to be implemented to treat and prevent possible subsequent problems. ${ }^{7}$

The clinical case study shows the development of skills and knowledge in a nursing process, in which nurses must have the ability to implement efficient actions towards holistic and organized nursing care. The use of nursing process in daily life of this this profession is of paramount importance in planning care, evaluating proposed actions, and to measuring quality of provided care and effectiveness of educational actions proposed by the nurse.

In view of that, the present study aims at reporting the experience of implementing nursing process in the phases of history, nursing diagnoses, planning and educational interventions when caring a patient with PI bedridden and assisted by the primary care health team.

\section{Method}

This is a descriptive exploratory study of an experience report, using nursing process in its phases of history, nursing diagnosis, planning, intervention, and results evaluation in line with Wanda Horta's theory on BHN. This experience took place in August, 2018 as home visit under Brazilian federal government program "the best program at home", which assists and monitors patients unable to attend a health unit.

The case study is an empirical investigation that deeply evaluates it in its real-world context, especially when boundaries separating phenomenon and context are elusive. 8,9 For this purpose, aforesaid investigation tool was used in the present study.

The patient was selected during a home visit aiming at elaborating care plan and guidelines for family caregivers of a PI patient. Study development used clinical case study model, which relies on nursing process and its sequential phases. It was possible to assess both patient's and his family's needs while proposing educational actions, by respecting legal references from the Brazilian Federal Nursing Council (COFEN) through resolution number 358/2009, which provides systematization for nursing as well as nursing process. ${ }^{8}$

As data collection technique involved nurses used Field Diaries to register clinical findings and addressed nursing diagnoses, especially those conceivably having benefits to patient and viable home execution. Notes were organized into five parts, namely: history, nursing diagnosis, planning, intervention, and evaluation of results.

Data were collected through data survey and interview with form completion under check-list style to include information on family history, age, sex, sanitation, housing, and pharmacotherapy as well as to record information collected on physical examination. When filling up the history, data were collected through physical examination and consultation of medical record in order to identify nursing diagnoses. In history implementation, physical examination was performed to assess patient while listing nursing interventions.

As methodological tool towards assistance guideline, Nursing Process includes the following steps: data collection, nursing diagnosis, nursing planning, implementation, and nursing evaluation.

For nursing diagnosis, NANDA International taxonomy (NANDA-1) was used. ${ }^{10}$ It is a basis for objectives and interventions according to Nursing Interventions Classification (NIC) ${ }^{11}$ and Nursing Outcomes Classification (NOC) $)^{12}$ taxonomies to meet specific needs of humans.

BHN theoretical framework was used to analyze patient's needs in line with Wanda Horta ${ }^{7}$ as based on MASLOW's theory of human motivation, which relies on basic human needs. Nursing is an applied science divided into two phases, with empirical phaseevolving toscientific one by means of theory development, knowledge systematization, research to scientifically materialize nursing assistance as well as planned and executed actions along with respective effectiveness of care.

Patient was informed about the proposed research, including its goals and involved procedures. The autho- 
rization term was signed as recommended by Resolution 466/2012 of the Brazilian National Health Council.

\section{Case report}

Male, 84 years old, brown skin, complete elementary school, retired, catholic, born in Três Corações (MG). Married; 2 grown-up children; living with one of them accompanied by the daughter-in-law and two grandchildren, aged 15 and 19; own house provided with sanitation, electricity and internet access.

Diagnosed with initial condition of senile dementia in May 2017, hypertensive and with PI as identified in nursing consultation on September 13, 2018 via "Melhor em Casa" (in English," Best at Home") program. During nursing consultation, patient was observed to have PI and, when assessed, patient's vital signs were measured as: $\mathrm{BP}=130 \times 60 \mathrm{mmHg}$, axillary temperature $=36.5^{\circ} \mathrm{C}, \mathrm{HR}=80 \mathrm{bpm}, \mathrm{R}=20$ irpm, capillary glucose $=$ $98 \mathrm{mg} / \mathrm{dL}$, pain $=+/ 4$ through visual analogue numeric pain scale.

Table 1 describes the PI with its characteristics, namely: lesion at right malleolus resulting from PI, stage III according to the National Pressure Ulcer Advisory Panel (NPUAP, 2016), with tissue loss of unknown depth, partially obscured by necrotic tissue in wound bed center and edges with granulation tissue. Lesion had rounded shape without exudate, granulation tissue at the edges and necrotic tissue at the center, measuring 2 $\mathrm{x} 2 \mathrm{~cm}$ and showing inflammation. His daughter-in-law requested his inclusion into the program through an 'UBS' in the metropolitan region of São Paulo city while reporting the difficulty in taking him to a health unit.

During the home visit, patient was bedridden with decreased visual acuity, lethargic, drowsy, confused, unresponsive, with decreased overall strength and reduced flexion, and lateralization movements of Lower Limbs, with PI grade 3 in right malleolus, dehydrated and with ecchymosis in right upper limb and left upper limb. Caregiver reported that patient had difficulty

Table 1. Features - right malleolus IP

\begin{tabular}{ll}
\hline Odor & Absent \\
Necrosis & Present at injury center \\
\hline Fibrin & Absent \\
\hline Exudate & Small presence \\
Edema & $++/++++$ \\
Pain & $\begin{array}{l}\text { When handling, pain was classified as } 4 \text { in } \\
\text { visual analog scale }\end{array}$ \\
\hline Dimension & Diameter $=2 \mathrm{~cm}$, depth $=7 \mathrm{~mm}$ \\
\hline
\end{tabular}

Authorship: The authors (2020). in eating (probable dysphagia) as well as little daily fluid intake, aggressive episodes of mental confusion, memory loss and pain at injury site. She also reported that patient suffered a fall two days before but he had not been taken to the emergency room.

With no protection bars on the bed and no support to reduce the risk of new falls, patient's home had inadequate lighting while it lacked stairs. Caregiver also reported that patient was taking the following medications: Risperidone 12/12 hours, Captopril $25 \mathrm{mg}$ once a day, and Omeprazol $20 \mathrm{mg}$.

\section{Results}

Patient findings were identified from physical examination and nursing interventions as indicated in Table 2 and Table 3, respectively. They include: dysphagia, inappetence, dehydration due to low water intake, impaired skin integrity due to long stay in bed, falling risk due to mental confusion crises and psychomotor agitation concomitant with decreased lower limb motor strength, apathy, anguish, PI presence in right malleolus, pain and difficulty in communication.

\section{Discussion}

In order to seek effective alternatives to meet population's health needs, aging process, epidemiological transition and health care model crisis have required efforts from health managers and professionals.

Bearing in mind its high incidence and decreased quality of patient's life in several areas (e.g. physical, emotional and social), PI is a public health problem. ${ }^{13} \mathrm{PI}$ can be related to internal and external factors to patient, while it results from pressure exerted on bony prominences, due to increased surface tension and/or shear stress. ${ }^{14}$

The National Pressure Ulcer Advisory Panel $(\text { NPUAP) })^{15}$ reports PI prevalence as $15 \%$ in USA while its incidence reaches up to 59.5\% in Brazil according to the literature. ${ }^{17}$ It is also worth recalling that the Ministry of Health aims at reducing PI risk as part of the six International Goals for Patient Safety. ${ }^{17}$

In view of this problem, home care can be defined as actions related to health promotion, disease prevention, and treatment and rehabilitation provided at home by a multiprofessional network, which mainly includes nursing. It aims at ensuring continuity to care by acting cohesively to Health Care Networks..$^{18,19}$ Ministry of Health Ordinance N. $963^{20}$ of 2013 defined the National Home Care Policy and the scope of "Best at Home" program. This health program includes bedridden elderly so that they can be assisted, as long 
Case report

Table 2. Clinical findings based on physical examination by systems

\begin{tabular}{l|l}
\hline Physical examination by systems & Clinical findings \\
\hline Neurological and Mental State & $\begin{array}{l}\text { Sleepy, confused, little communicative. } \\
\text { Decreased visual acuity, preserved hearing without the presence of cerumen in ear cavities, } \\
\text { isophoto-reactive pupils, partially incomplete dentition, without the presence of lesions in oro- } \\
\text { pharyngeal cavity. } \\
\text { Neck: Absence of palpable nodes. }\end{array}$ \\
\hline Cardiopulmonary & $\begin{array}{l}\text { Thorax: symmetrical, with good expandability with irregular hair distribution. } \\
\text { Pulmonary auscultation: well-distributed breath sounds, percussion - clear lung sound. } \\
\text { Cardiac auscultation: BRNF2T, with no noticeable changes. }\end{array}$ \\
\hline Gastrointestinal & $\begin{array}{l}\text { Abdomen: Flaccid } \\
\text { Auscultation: tympanic sound in the inguinal region D, flank D, Hypochondrium D, Epigastric, } \\
\text { Hypochondrium E, RHA +; percussion: massive sound in Flank E and Inguinal E. }\end{array}$ \\
\hline Genitourinary & $\begin{array}{l}\text { Unevaluated genitalia. } \\
\text { Skeletal muscle }\end{array}$ \\
\hline Legument & $\begin{array}{l}\text { Leffon by grade-2 pressure in malleolus D } \\
\text { Decreased overall strength and reduced flexion and lateralization movements of upper limbs, } \\
\text { peripheral perfusion. }\end{array}$ \\
\hline Intense scalp without dirt presence, decreased skin Turgor, presence of ecchymosis in Right \\
Upper Limb (RUL) and Left Upper Limb (LUL) with irregular distribution.
\end{tabular}

Authorship: The authors (2020).

as patient is bedridden and bears a home caregiver, whether family member and/or service provider.

A chronic injury is a pathology that tends to be progressive and cause several complications if not treated properly. Chronic injuries burden public spending, jeopardize patients' life quality, hinders rehabilitation, delays return to work and leisure activities, besides exposing them to death risk. ${ }^{19}$

It is up to nurses to develop both care and prevention routines towards PI, seeking theoretical bases to reduce factors leading to this pathology, thus promoting safe and quality care to the patient. ${ }^{21}$ According to Soares et $\mathrm{al}^{22}$, in order to control and reduce PI indices, nurses must be knowledge multipliers, carrying out continuing education (especially health education) not only to their teams but to everyone directly linked to patient management as means to promote patient safety and thus reducing PI incidence and/or worsening.

Along with nursing students, the team of "Best at Home" assisted the case-selected elderly. It was then possible to confirm the effectiveness of model indicated in Health Care Protocol, ${ }^{23,24}$ which states that guidance to patients and companions is essential despite measures to PI prevention and care.

The patient safety guide for home care ${ }^{25}$ points out for the care to be performed not only by caregivers but also patients themselves such as hydrating skin, changing patient position, and monitoring bed head height, which are important modifying factors. It was a posteriori assessed that guidelines on those factors provided by nursing students to caregivers indeed prevented the incidence of new PI in the patient.

The Systematization of Nursing Assistance (SAE) is the support instrument whose main function is to ensure a scientific efficient basis to propose both techniques towards PI patients care and decision-making/ preparation of health care plan to the patient with quality and responsibility. However, most of the studies found in a related bibliographic survey refer to PI epidemiology, costs, time, and treatment types. ${ }^{23}$

It was possible to observe that nurses have a fundamental role in guiding caregivers with respect to good prognosis of PI as they are able to promote injury prevention actions whenever well-oriented. Consequently, it is possible to improve the life quality of bedridden patients with self-care limitations resulting from changes related to the aging process.

\section{Study limitations}

Limitations in the present case report referred to scarcity of articles on the topic with the desired focus as well as to limited contact time with patient and caregiver. 


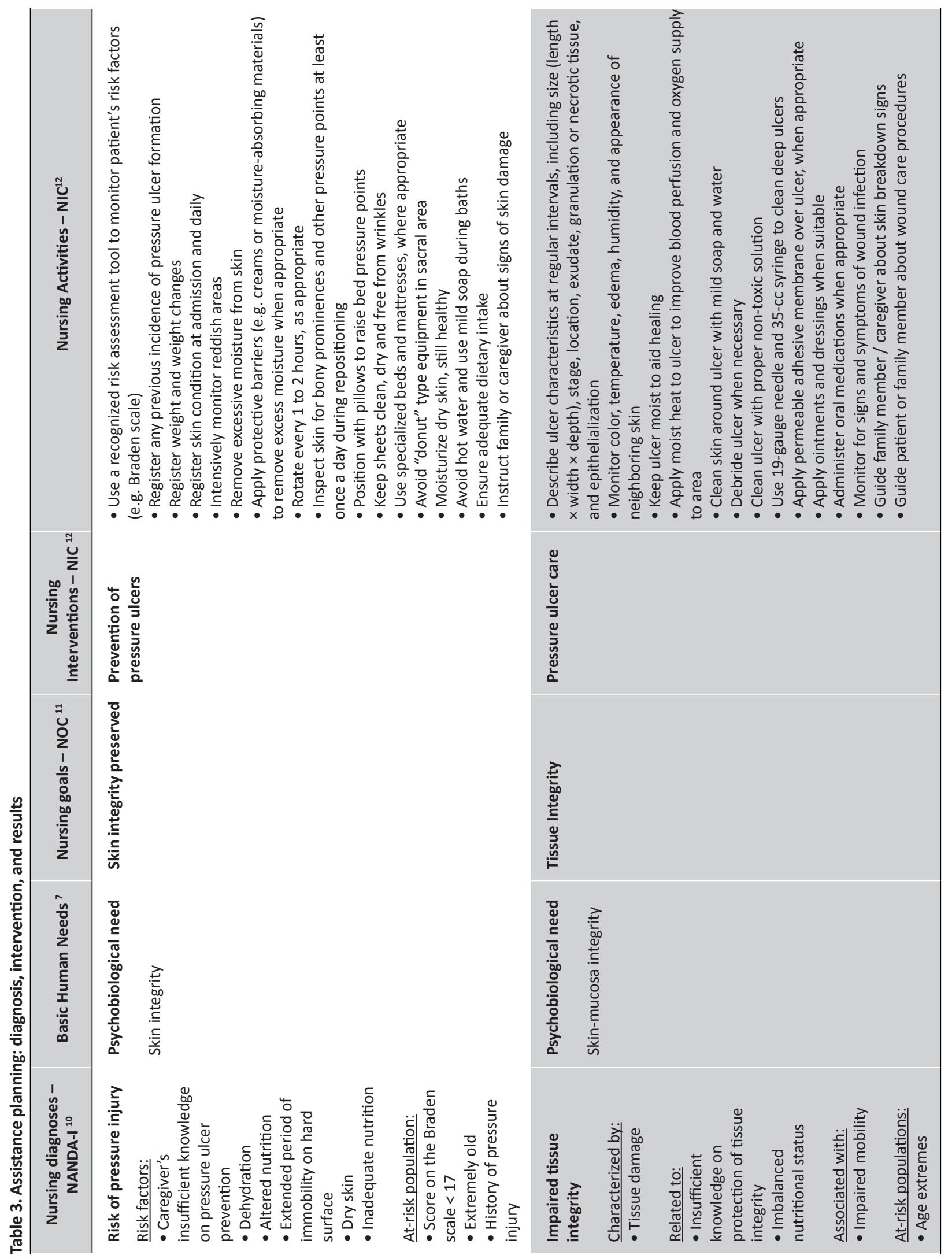




\section{Case report}

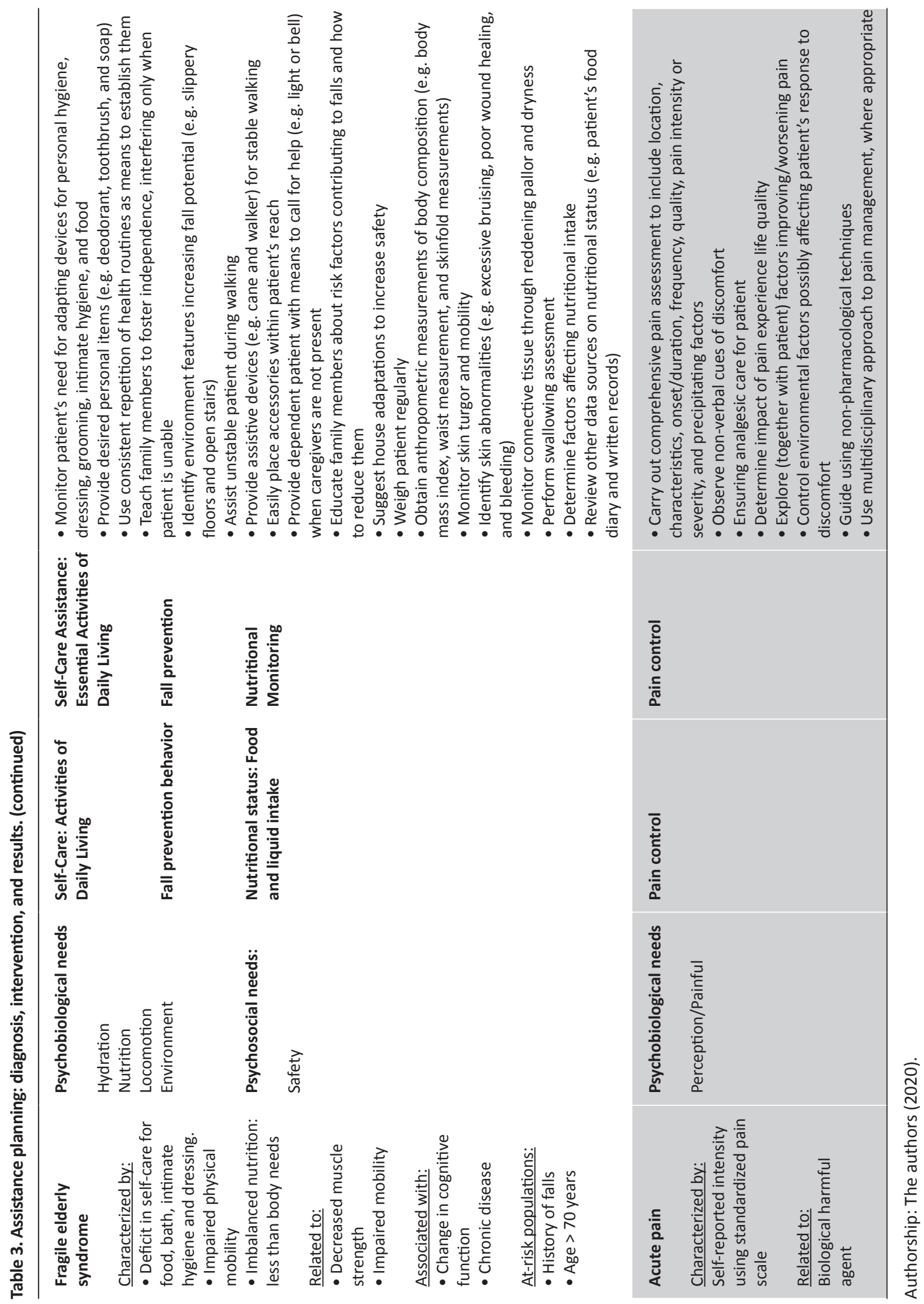




\section{Conclusions}

As addressed in this study, the application of the nursing process demonstrated that evidence-based nursing along with scientifically supported actions lead to effectiveness and quality in both care and guidance provided to patient/caregiver. This overcomes empirical and retrograde nursing care concepts, thus prioritizing focus on the patient as complex and complete human being, who needs holistic view of bio-psycho-social-spiritual needs, moving towards health in terms of whole well-being of body, mind and spirit in total harmony.

The present study pointed to the importance of health education by home care nurses through "Best at Home" program for caregivers-dependent patients, who are outside hospital environment. Nursing has transcended the simple provision of direct patient care towards guidance, teaching, and awareness. This

\section{Referências}

1. Moraes JT, Borges EL, Lisboa CR, et al. Conceito e classificação de LP: atualização do National Pressure Ulcer Advisory Panel. Revista de Enfermagem do Centro-Oeste Mineiro. 2016 jun. 29;6(2).

2. Soares CF, Heidemann IT. Promoção da saúde e prevenção da lesão por pressão: expectativas do enfermeiro da atenção primária. Texto \& Contexto-Enfermagem. 2018;27(2).

3. Cheever KH, Hinkle JL. Brunner \& Suddarth. Tratado de enfermagem médico-cirúrgica. Rio de Janeiro: Guanabara Koogan; 2016.

4. Pieper M. Pressure ulcers: prevalence, incidence, and implications for the future. 2 ed. Washington: National Pressure Ulcer Advisory Panel, 2012.

5. Borges EL, Fernandes FP. Úlcera por pressão. In: Domansky $\mathrm{RC}$, Borges EL. Manual para prevenção de lesões de pele: recomendações baseadas em evidências. 2a. ed. Rio de Janeiro: Rubio; 2014.

6. Studart RM. A escala de Waterlow na úlcera por pressão em pessoas com lesão medular: uma tecnologia assistencial de enfermagem.

7. Horta WA. Processo de Enfermagem. São Paulo (SP): EPU; 1979.

8. De Enfermagem CF. Resolução COFEN-358/2009. Dispõe sobre a sistematização da assistência de enfermagem-SAE nas instituições de saúde brasileiras. Brasília. 2009 Oct. [Acess on 10 jun 2020] Available at: http://www.cofen.gov.br/resoluocofen-3582009_4384.html

9. Yin RK. Estudo de Caso: Planejamento e métodos. Bookman editora; 2015.

10. Herdman TH, Kamitsuru S, tradução: Garcez R.M: Revisão técnica: Barros A.L.B.L et al. Diagnósticos de enfermagem Nanda: definições e classificação 2015-2017.10a. ed. Porto Alegre: Artmed 2015. 468 p.il.

11. Bulechek GM, Dochterman JM, Butcher HK, et al. Classificações das intervenções em enfermagem NIC, tradução de Denise Costa Rodrigues, 6a. ed. Rio de Janeiro: report evidences that, as health educators, nurses play a key role in preventing risk exposure to either elderly patients or patients depending on home care from lay people lacking necessary knowledge to meet patients' needs as demanded by their degraded health condition.

During practical activities related to disciplines such as "Health of the Elderly", "Adult Health" and "Nursing Care Processes", implementation of the Nursing Care Systematization (SAE) provided knowledge on NANDA-1, NIC and NOC taxonomies to develop care plans to PI patients. Among other concomitant diagnoses, aforesaid nursing experience favors early improvement prospect in patients while reinforcing nursing work credibility.

Finally, the need to expand scientific production in this knowledge area becomes evident so that nurses may rely on scientific evidence to perform their role with excellence.

Elsevier, 2016.

12. Moorhead S, Moorhead M, Johnson M, et al. NOC Classificação dos resultados de enfermagem. Elsevier Brasil; 2015 Nov 10.

13. Oliveira DM, Costa MM, Malagutti W. Intervenções de enfermagem para pacientes com lesão por pressão. Rev. Enferm. UFPE on line. 2019:1-0.

14. Ayello EA, Cordero GM, Sibbald RG. Survey results from Canada and some Latin America countries: 2016 National Pressure Ulcer Advisory Panel changes in terminology and definitions. Adv Skin Wound Care. 2017 Feb;30(2):71-6.

15. National Pressure Ulcer Advisory Panel. NPUAP pressure injury stages. Washington: NPUAP; 2016 [cited on 2018 Aug 10]. Available at: http://www.npuap.org/about-us/

16. Tomazini Borghardt A, Nascimento do Prado T, Silveira Bicudo $\mathrm{SD}$, et al. Pressure ulcers in critically ill patients: incidence and associated factors. Revista Brasileira de Enfermagem. 2016 May 1;69(3).

17. Ministério da Saúde (BR), Gabinete do Ministro. Portaria $N^{\circ}$ 529 de $1^{\circ}$ de abril de 2013. Institui o Programa Nacional de Segurança do Paciente. Brasília: Ministério da Saúde; 2013 [cited on 2020 set 30]. Available at: http://bvsms.saude.gov.br/ bvs/saudelegis/gm/20 13/prt0529_01_04_2013.html

18. Malagutti W. Assistência domiciliar atualidades da assistência de enfermagem. Editora Rubio; 2012 Jan 17.

19. Barros MP, de Oliveira Ferreira PJ, Maniva SC, et al. Caracterização de feridas crônicas de um grupo de pacientes acompanhados no domicílio. Revista Interdisciplinar. 2016;9(3):1-1

20. Brasil. Portaria n 963 do Ministério da Saúde. Ato de 2013. Pub. Diário Oficial da União - DOU, n 101. 30-32, Secção 1 (27 de maio de 2013).

21. Moreira RAN, Queiroz TA, Araújo MFM, et al. Condutas de enfermeiros no tratamento de feridas numa unidade de terapia intensiva. Rev Rene Fortaleza. 2009 jul-set; 10(3):83-9.

22. de Avila Soares RS, Real Saul AM, da Silva RM, et al. Intervenção educativa como processo de construção do conhecimento no cuidado da úlcera por pressão. Journal of 


\section{Case report}

Nursing UFPE / Revista de Enfermagem UFPE. 2014 Jun 1;8(6). 23. Brasil. Segurança do Paciente: prevenção de Lesão por Pressão (LP). Fernandes, LM, \& Caliri, MHL (2008). Using the braden and glasgow scales to predict pressure ulcer risk in patients hospitalized at intensive care units. Revista LatinoAmericana de Enfermagem. 2017;16(6):973-8.

24. Brasil. Ministério da Saúde. Protocolo para prevenção de úlcera por pressão, 2013. Available at: ///C:/Users/14405180/ Downloads/protoc_ulceraPressao.pdf. Access on 04 Oct 2020. 25. Brasil. Ministério da Saúde. Secretaria de Atenção à Saúde. Departamento de Atenção Hospitalar e de Urgência. Segurança do paciente no domicílio/Ministério da Saúde, Secretaria de Atenção à Saúde, Departamento de Atenção Hospitalar e de Urgência. Brasília: Ministério da Saúde, 2016. 